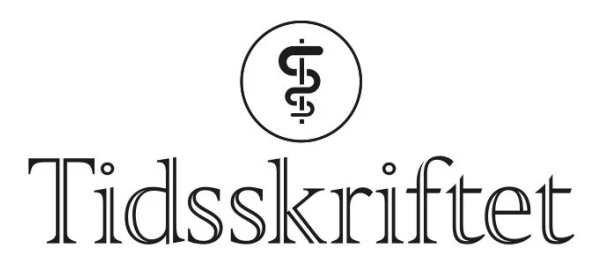

DEN NORSKE LEGEFORENING

\title{
Egil Wilhelm Martinsen
}

MINNEORD

MARIT BJARTVEIT

SVEIN FRIIS

ELLEN HAGEMO

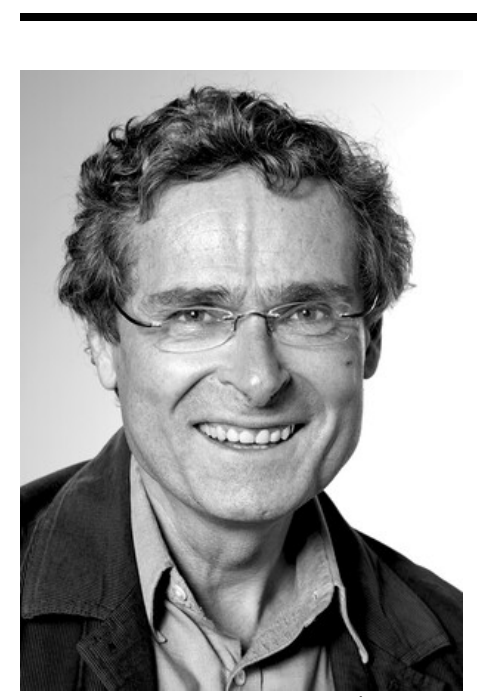

Foto: Øystein Horgmo / UiO

Egil W. Martinsen døde 28. desember, 71 år gammel. Med ham er en markant skikkelse i norsk psykiatri gått bort. Han ble cand.med. i 1976 og kom til Modum Bad som assistentlege tidlig i 1980-årene. Spesialist i psykiatri ble han i 1985. Med stipend fra Forskningsrådet gjennomførte han et banebrytende arbeid om fysisk aktivitet i behandlingen av psykiske lidelser.

Han disputerte i 1989. Avhandlingen vakte stor oppsikt, også internasjonalt, og gjorde Egil til en autoritet på betydningen av fysisk aktivitet for behandling og forebygging av psykiske lidelser. Med et sterkt $\emptyset$ nske om å bidra med sin fagkompetanse der hvor den trengtes mest, dro han i 1988 til Førde og satte sitt sterke preg på utviklingen av psykiatrien i Sogn og Fjordane. 
I 2000 kom han tilbake til Modum Bad som forskningsleder. Gjennom tett integrasjon med klinisk praksis fikk Forskningsinstituttet under Egils ledelse stor betydning for den sterke faglige og behandlingsmessige utviklingen av Modum Bad i disse årene, blant annet som pådriver for å integrere rus og avhengighet $\mathrm{i}$ behandlingen av psykiske lidelser.

I 2007 ble han tilsatt som professor ved Gaustad, Klinikk psykisk helse, Aker universitetssykehus. Å få en tettere tilknytning til Universitetet og å kunne undervise studenter var noe han $\emptyset$ nsket, og han satte spor etter seg hos studentene med sin brede kunnskap og pedagogiske tilnærming. Han beriket klinikken med visjoner og evne til å knytte kontakt med mange miljøer, og han deltok også i sykehusets åpne dager.

Da sykehusfusjonen skapte Oslo universitetssykehus i 2010, ble han avdelingsleder for den sammenslåtte Forsknings- og utviklingsavdelingen (FoU) i Klinikk psykisk helse og avhengighet. Egil var opptatt av fagutvikling av og forskning på klinikkens tre fagområder: psykisk helse for barn og unge og for voksne samt tverrfaglig spesialisert behandling av ruslidelser. Fra 2017 prioriterte han forskning og undervisning på fulltid.

Egil understreket helhetsperspektivet i behandling og rehabilitering og var opptatt av hvordan helsepersonell kan bidra til å styrke livsmot og livskrefter hos brukere og pasienter. Gjennom hele sitt kliniske virke var han opptatt av kognitiv terapi, som lærer, foreleser, veileder og leder av Norsk Forening for Kognitiv Terapi. Han var samtidig opptatt av å kombinere kognitiv terapi med andre terapiformer, særlig fysisk aktivitet.

Egil vil bli savnet som en god venn med lun, folkelig humor. Våre tanker går til dem som har lidd det største tapet, hans kone Lisbet og sønnene Anders og Audun med familie.

Publisert: 31. januar 2022. Tidsskr Nor Legeforen. DOI: 10.4045/tidsskr.22.0022

(C) Tidsskrift for Den norske legeforening 2023. Lastet ned fra tidsskriftet.no 26. april 2023. 